\title{
ResearchPaPer
}

\section{In vitro and vivo evaluation of some fungicides and organic amendments to control of Fusarium solani causing Indian Aloe (Aloe barbadensis) root}

\author{
MUKESH KUMAR JAT AND R.R. AHIR
}

\begin{abstract}
SUMMARY
Investigation on root rot (Fusarium solani) of Indian aloe (Aloe barbadensis Mill.) under jobner conditions was carried out in Department of Plant Pathology Lab., S.K.N. College of Agriculture Jobner to find out sutaible management strategies. Trials on the use of some fungicides and organic amendments to control the pathogen. Among five fungicides viz., Benomyl, Thiophanate methyl, Captan, Carbendazim and Thiram and in case organic amendments neem cake, Vermicompost, Goat and Sheep manure, Mustard Cake and Wool Waste tested in different concentrations against Fusarium solani by following Poisoned Food Technique. Benomyl was found best with complete inhibition of the mycelial growth at 200 and 300 ppm concentrations, followed by Thiophanate methyl and Neem cake (79.0\%) was found most effective in reducing mycelial growth of the fungus followed by Vermicompost (74.8\%) effective against Fusarium solani. The effect of combinations of different fungicides and organic amendments against Fusarium solani were tested in vivo (pot house) condition Benomyl + Neem cake combination $(0.3 \%+1.25 \mathrm{~g} / \mathrm{kg}$ soil) was found best with minimum per cent disease incidence $(12.00 \%)$ followed by Thiophanate methyl + Neem cake $(16.00 \%)$, Benomyl + Vermicompost (20.00\%) which were observed to be less effective as compared to other fungicides and organic amendments.
\end{abstract}

Key Words : Indian Aloe, Fusarium solani, Fungicides, Organic amendment, Neem cake, Vermicompost

How to cite this article : Jat, Mukesh Kumar and Ahir, R.R. (2017). In vitro and vivo evaluation of some fungicides and organic amendments to control of Fusarium solani causing Indian Aloe (Aloe barbadensis) root. Internat. J. Plant Sci., 12 (1): 90-94, DOI: 10.15740/HAS/IJPS/12.1/90-94.

Article chronicle : Received : 15.07.2016; Revised : 02.12.2016; Accepted : 30.12 .2016

\section{MEMBERS OF THE RESEARCH FORUM}

Author to be contacted :

MUKESH KUMAR JAT, Department of Plant Pathology, S.K.N. College

of Agriculture, JOBNER (RAJASTHAN) INDIA

Email: mksepat@gmail.com

Address of the Co-authors:

R. R. AHIR, Department of Plant Pathology, S.K.N. College of Agriculture, JOBNER (RAJASTHAN) INDIA 